\title{
Evaluation of Onion Varieties for Productivity Performance in Botswana
}

\author{
Som Pal Baliyan* \\ Department of Agriculture, Livingstone Kolobeng College, Gaborone, Botswana \\ *Corresponding author: spbaliyan@yahoo.com
}

Received April 17, 2014; Revised May 29, 2014; Accepted June 03, 2014

\begin{abstract}
Onion varieties were evaluated for adaptability to the climatic conditions in Botswana. Six varieties of onion were planted under a complete randomized block design experiment with four replications at farmers' field in Botswana (Southern Africa). The quantitative data on yield of onion varieties and, farmers perception on the varieties were collected. All the varieties were harvested at their maturity (80\% tops down) and then graded and weighed into six categories of bulbs: small weight, double weight, thin weight, bolters weight, marketable weight and total weight. Inferential and descriptive statistical methods were used for data analysis where by two ways analysis of variance and ranking scales were applied. It was concluded that all the six varieties namely; Arad, Galil, Hanna, Shahar, Texas Grano 502 P.R.R. and Red Creole contributed differently to the total yield, marketable yield and percentage marketable yield. Onion variety Hanna followed by Shahar produced the highest marketable yield whereas Galil variety gave the lowest marketable yield. Despite the fact that Texas Grano variety produced the highest total yield and has been a common and popular onion variety in Botswana, it was recommended that farmers should not grown Texas Grano variety as it produced the lowest percentage (60\%) of marketable yield. Based on the yield performance and the farmer's perception, Hanna followed by Shahar varieties were found to be the best performing onion variety and therefore, government should promote these onion varieties for cultivation in Botswana. Government can import to ensure the availability of Hanna and Shahar varieties so that farmers can be motivated for adoption of these varieties for commercial production. The effects of different planting dates on the yield of onion varieties can be considered for future research.
\end{abstract}

Keywords: onion productivity, onion varieties, on-farm evaluation, adaptation, yield performance, Botswana

Cite This Article: Som Pal Baliyan, "Evaluation of Onion Varieties for Productivity Performance in Botswana.” World Journal of Agricultural Research, vol. 2, no. 3 (2014): 129-135. doi: 10.12691/wjar-2-3-8.

\section{Introduction}

Onion (Allium cepa) belongs to the family Liliaceae, an important group of crops worldwide (Best, 2000). Onions exhibit particular diversity in the eastern Mediterranean countries, through Turkmenistan, Tajikistan to Pakistan and India, which are the most important sources of genetic diversity and believed to be center of origin (Brewster, 2008). In terms of global weight of vegetables produced, at nearly 28 million tons per annum, only tomatoes and cabbages exceed bulb onions. Onion is one of the oldest bulb vegetables in continuous cultivation dating back to at least 4000 BC (Ahmad et al., 2008; Hayslip et al., 1987). Onions are grown mainly as food materials however; onion has medicinal properties and has been used for the treatment of various ailments such as skin diseases, ear pain, heart attack and strokes. The bulbs are boiled and used in soups and stews, fried or eaten raw in salads. Although its main role in cooking is to provide flavor, onion is a significant source of vitamin $\mathrm{C}$ and potassium, contains about 60 calories in a medium-sized bulb, and has very low sodium content. The crop nutritional composition includes $2.0 \mathrm{~g}$ protein, $70 \mathrm{mg}$ calcium and 53 mg phosphorus (Ado, 2001). It also contains the vitamins thiamine, riboflavin and niacin and is used for its medicinal value especially in the case of heart problems (Mettananda and Fordham, 2001). They also contain a phytochemical called quercetin, which is effective in reducing the risk of cardiovascular disease, an anticancer, and has promise to be an antioxidant (Smith, 2003).

A cultivar crop performs differently under different agro-climatic conditions and various cultivars of the same species grown even in the same environment give different yields as the performance of a cultivar mainly depends on the interaction of genetic makeup and environment (Jilani \& Ghafoor, 2003; Kimani et al. 1993). Ijoyah et al (2008) conducted a field experiment to evaluate the yield performance of four onion varieties and found that some other varieties performed better than the commonly grown onion varieties by the farmers. Shah, et al (2012) conducted an evaluation trial of three onion cultivars in Randomized Complete Block Design having three replications and concluded that onion cultivar performed differently and Parachinar local variety resulted in higher yield.

Onion is a winter season cash crop and grown throughout Botswana. The production of onions in Botswana is very low which can only meet $18 \%$ of the 
local demand (FAO. 2012) and therefore, the country depends on import of dry (mature) to meet the local demand of onion. On good soils, yields of over $60 \mathrm{t} / \mathrm{ha}$ are possible. However, 40 t/ha is more typical (Department of Agricultural Research, 2006) which is below the world average onion yield. The low productivity of vegetables including onion in Botswana is attributed to a number of yield reducing factors which include among others low yielding varieties, harsh climate and poor soils (Baliyan and Kgathi, 2009). In Botswana winter is too short but temperatures can touch to the lowest of $-4^{\circ} \mathrm{C}$. On the other hand, very high temperatures in summer season which sometimes touches to $45^{\circ} \mathrm{C}$. As onion requires long winter for proper growth and development of bulb, it becomes very difficult to produce good yield. Apart from the good management and cultural practices, development of new varieties and evaluation of the available onion varieties are the sustainable strategies to improve the productivity and production of onions. The development of new varieties is a long and expensive process which also needs expert scientists especially, plant breeders. However, the evaluation of the existing and available onion varieties for their adaption and productivity in the climatic conditions of Botswana is a faster way to improve the onion production. The farmers choose onion variety for planting depending on a number of factors which include production potential, market demand, regional adaptability and availability of seeds and their prices. The availability of seeds and the cost of seeds affect the adoption of the varieties by the farmers. If the seeds are expensive and difficult to obtain, the farmers find other available cheaper varieties in the local market which usually are low productive. Therefore, the perception of farmers is also important while selection and evaluating the varieties. Although several high yielding varieties and hybrids have been introduced during the last decades, there is a potential need for them to be evaluated in the agroclimatic conditions of Botswana. Most vegetable cultivar trials including onion focus on yield and quality attributes and are implemented on research stations (Wiles 2006; Anon, 1985-1987). However, yield performance of varieties has hardly been evaluated on on-farm conditions in Botswana.

Observing the importance of onion crop and the varieties, the on-station variety trials of varieties of onion was started at Boro research station, Maun, Department of Agricultural Research, Ministry of Agriculture, Republic of Botswana. The purpose of the on-station variety evaluation trials was to identify promising onion varieties and thus provide up-to-date variety recommendations for the onion growers. Before any final variety recommendation is made, it is extremely important to evaluate the varieties on farmer's field for their adaptation and productivity performance. Therefore, on-farm trials were conducted for evaluation of six promising varieties of onion in Botswana. The six selected onion varieties considered for this experiment were the highest yielding varieties out of many varieties under on-station trials which yielded between 50-70 tons per hectare (Wiles, 2006; Department of Agricultural Research, 2006). Obviously, it was hypothesized that the selected six varieties will adapt and produce high yields in on-farm conditions. The on-farm trials were conducted for two consecutive years but this study presents the results of the second trial. The objective of the on-farm trials was to evaluate the yield performance and productivity of promising varieties of onion on farmer's fields in Botswana and also to obtain farmer perceptions on the varieties evaluated.

\section{Materials and Methods}

A Researcher Managed and Farmer Implemented (RMFI) onion variety evaluation trial was conducted at farmer's field in Maun, Botswana (Southern Africa). A randomized complete block design with four replicates was used. Seeds of six varieties of bulb onion namely; Arad, Galil, Hanna, Shahar, Texas Grano 502 P.R.R. and Red Creole were sown in seedbeds. Eight weeks old seedlings were transplanted in plots of $6 \mathrm{~m} \times 0.6 \mathrm{~m}$. Each plot consists of two 6 meter long rows. Row to row and plant to plant spacing was $30 \mathrm{~cm}$ and $7.5 \mathrm{~cm}$ respectively. Prior to transplanting, $750 \mathrm{~kg} / \mathrm{ha}$ 2:3:2 fertilizer was applied as basal fertilizer before planting and $140 \mathrm{~kg} / \mathrm{ha}$ Urea was top dressed six weeks after transplanting. The sprinklers method was used for irrigating the onion crop. All the recommended cultural practices in growing of onion were followed. However, no farm chemical was applied as all the varieties were growing healthy and no pest and disease problem was observed. All the varieties were harvested once as per their maturity stage (80\% tops down). The harvested onions of all varieties were left to dry in shade for a week and then the leaves were removed to get the dry bulbs of onion (Appendix 1). Thereafter, harvested onions were graded, weighed and recorded into six categories of bulbs namely; marketable weight, small weight, double weight, thin weight, bolters weight and total weight.

Inferential and descriptive statistical methods were used for data analysis where by two ways analysis of variance and ranking scales were applied. The quantitative data on yield was analyzed using a two-way analysis of variance, using the SPSS program version 19. Treatment means were separated using Fisher's Least Significant Difference (LSD) (Steel and Torrie, 1980). A related question of interest of study was to examine whether the two factors under consideration namely, varieties of onion and experimental blockings had any impact on harvested onion bulb categories such as (i) small onion bulbs weight, (ii double onion bulbs weight, (iv) thin onion weight and,(v) bolters weight. To answer these questions, a two way analysis of variance was carried out by considering the variety and replication as independent factors and; the four categories of onion weights as the dependant variables.

Focus group interviews were held with group of horticultural farmers to obtain their perceptions on the onion varieties under evaluation. The focus group is an established method of social inquiry (Greenbaum, 1993; Krueger, 1998) and a reliable and cost effective method to obtain the perception on any aspect. The horticultural farmers in Botswana are scattered and it was not possible for the researcher to reach to individual farmers because of the time and financial constraints. Therefore, a group of 30 farmers were invited to visit twice the trial site and were asked for their perceptions on the onion varieties under evaluation based on the specified criteria of yield, 
availability of seeds, shape, size and color of onion bulbs. The farmers were provided with a prepared onion varieties rating sheet indicating these criteria and were asked to give their perception (preference) by ranking the six onion varieties under evaluation.

\section{Results and Discussion}

\subsection{Yield Performance of Onion Varieties}

A two-way analysis of variance was conducted to examine whether the six onion varieties differ significantly for their total yield, marketable yield and percent marketable yield. The results of two way variance analysis for their total yield, marketable yield and percent marketable yield presented in Table 1, Table 2 and Table 3 , respectively. Table 1 reveals that total yields of six onion varieties differ significantly $(\mathrm{p}<.001)$, while there are no significant effect of replications $(p=.132)$. Table 2 reflects that marketable yields of six onion varieties differ significantly $(\mathrm{p}<.001)$, while there are no significant effect of the replications ( $p=.556$ ). It can also be observed that the percentage marketable yields of six onion varieties differ significantly $(\mathrm{p}<.001)$, while there are no significant effect of the replications $(p=.878)$ (Table 3). Therefore, it can be concluded that the six variety (treatment) combinations, namely Arad, Galil, Hanna, Shahar, Texas Grano 502 P.R.R. and Red Creole contribute differently to the total yield, marketable yield and percentage marketable yield of onion. However, the total yield, marketable yield and percentage marketable yield of onion does not seem to be impacted by the layout of experiment in the field and its conduction. It implies that the onion varieties has responded to the climatic conditions of Botswana and reflected significantly their productivity performance. These results are similar to the findings of Jilani \& Ghafoor, (2003); Kimani et al. (1993) reported that various cultivars of the same species grown in the same environment give different yields as the performance of a cultivar mainly depends on the interaction of genetic makeup and environment.

Table 1. Influence of Different Varieties (Treatments) of onion on the Yield of onions

\begin{tabular}{cccccc}
\hline Source & SS & df & MS & F & Sig \\
\hline Replications & 89.585 & 3 & 29.862 & 2.187 & .132 \\
Treatments & 2187.320 & 5 & 437.464 & 32.045 & $<.001$ \\
Error & 204.775 & 15 & 13.652 & & \\
Total & 2481.681 & & & & \\
\hline
\end{tabular}

R square $=.917$, Adjusted R square $=.873$

Table 2. Influence of Different Varieties (Treatments) of onion on Marketable yield of onions

\begin{tabular}{cccccc}
\hline Source & SS & df & MS & F & Sig \\
\hline Replications & 41.962 & 3 & 13.987 & .718 & .556 \\
Treatments & 1638.131 & 5 & 327.626 & 16.826 & $<.001$ \\
Error & 292.066 & 15 & 19.471 & & \\
Total & 1972.158 & 23 & & &
\end{tabular}

R square $=.852$, Adjusted R square $=.773$
Table 3. Influence of Different Varieties (Treatments) of onion on Marketable percentage yield of onions

\begin{tabular}{cccccc}
\hline Source & SS & df & MS & F & Sig \\
\hline Replications & 52.066 & 3 & 17.355 & .225 & .878 \\
Treatments & 2966.301 & 5 & 593.260 & 7.678 & $<.001$ \\
Error & 1159.082 & 15 & 77.272 & & \\
Total & 4177.449 & 23 & & &
\end{tabular}

R square $=.723$, Adjusted R square $=.575$

Table 4 presents the partial output of a two way analysis of variance carried out to assess the significance of the two factors of interest (variety and replication) on the four categories of onion bulbs namely; small weight, double weight, thin weight and bolters weight. It is revealed that onion varieties do significantly affect all the bulb categories under consideration except bulb categories of small bulb and bolters bulb. It implies that these onion varieties did not produce small and bolters bulbs in significant numbers which could have affected the total yield and therefore the total yield was not influenced by these two categories of onion bulbs. The homogeneity of replications (blocks) in which six onion varieties are replicated is confirmed (insignificant p-values) in the case of all four bulb categories. It reflected that the experiment was planned and managed effectively and factors such as irrigation, soil fertility, pest and diseases and other environmental conditions had no significant influence on the productivity of the onion varieties. Table 4 reflected that the bulb categories namely; double onion and thin onion for all the six onion varieties differ significantly ( $p$ $<$.001). On the other hand, there are no significant effect of the replications on any of the onion bulb categories namely; small weight, bolters weight, double weight and thin weight ( $\mathrm{p}=.327, .564, .978$ and .776 , respectively). It indicated that none of the four bulb categories of onions are affected by the design of the layout and conduction of the experiment such as irrigation, soil fertility, pest and diseases and other environmental conditions. These results indicated that all the onion varieties do have adverse affect in terms of the quality of onion produced as it affect significantly the marketable yield of onions negatively. This finding is consistent with the finding in case of total onion weight alluded to earlier as all the dependent variables under the two way analysis of variance carried out is related to the total yield weight.

Table 4. Summary of Two-way ANOVA: Effect of Treatments (Varieties) and Replications (Blocks) on Onion bulb category variables

\begin{tabular}{cccc}
\hline $\begin{array}{c}\text { Sr. } \\
\text { No }\end{array}$ & $\begin{array}{c}\text { Factors (Independent } \\
\text { Variable) }\end{array}$ & $\begin{array}{c}\text { Dependent } \\
\text { Variables }\end{array}$ & p-value \\
\hline 1 & Varieties & Small onion & .326 \\
Weight & & .327 \\
2 & Replications & Bolters Weight & .261 \\
& Varieties & & .564 \\
3 & Replications & Double onion & $<.001^{* *}$ \\
& Replications & Weight & .978 \\
& Varieties & Thin onion Weight & $<.001^{* *}$ \\
& Replications & & .776 \\
\hline
\end{tabular}

Note: **: significant at $1 \%$ level 
Table 5. Marketable and Total Yield (t/ha) and Percentage Marketable Yield of onion varieties

\begin{tabular}{cccc}
\hline Variety & Marketable Yield & Total Yield & \%Marketable \\
\hline Hanna & 43.01 & 50.60 & 84.33 \\
Shahar & 35.42 & 40.51 & 87.10 \\
Texas Grano 502 PRR & 32.22 & 54.07 & 60.05 \\
Red Creole & 22.87 & 28.19 & 81.17 \\
Arad & 22.59 & 33.97 & 66.42 \\
Galil & 19.86 & 32.22 & 61.72 \\
\hline
\end{tabular}

Total yield, marketable yield and marketable percentage yield of onion varieties are presented in Table 5 indicating that onion variety Texas Grano produced the highest total yield whereas lowest total yield produced by Galil. Figure 1, Figure 2 and Figure 3 show the estimated marginal means of total yield, marketable yield and percentage marketable yield of six varieties over the four replications, respectively.

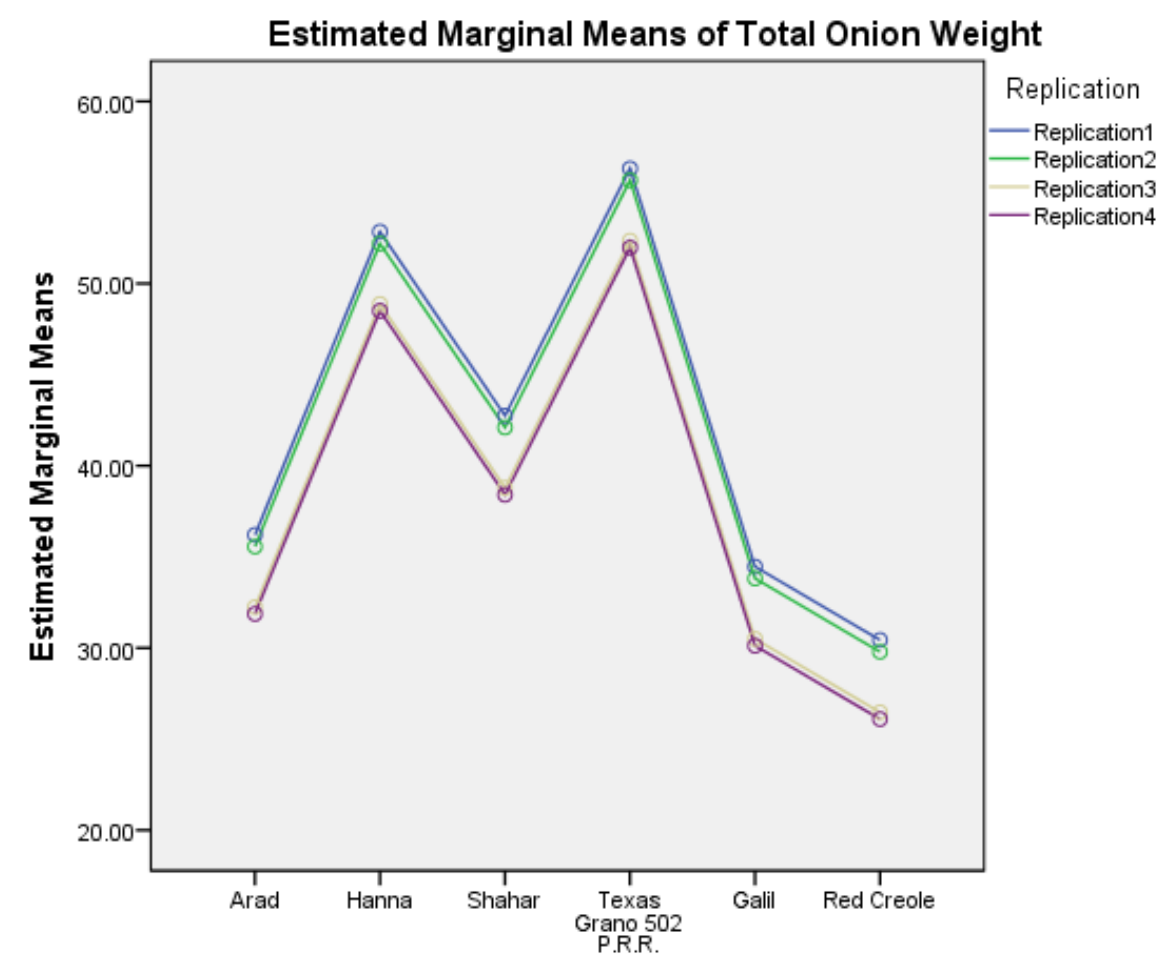

Treatment

Figure 1. Estimated marginal means of total yield (t/ha) of six varieties over the four replications

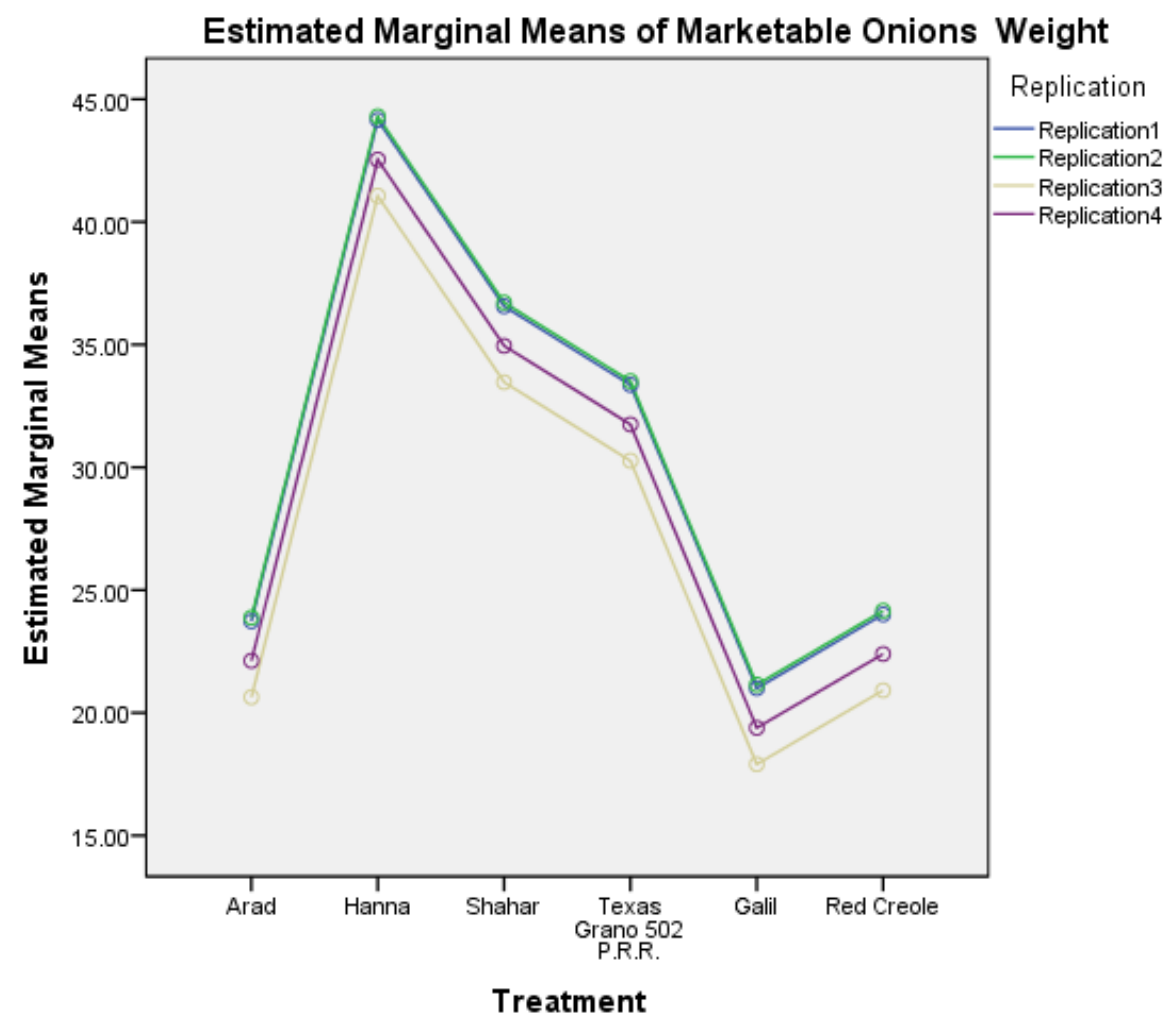

Figure 2. Estimated marginal means of marketable onions yield (t/ha) of six varieties over the four replications 


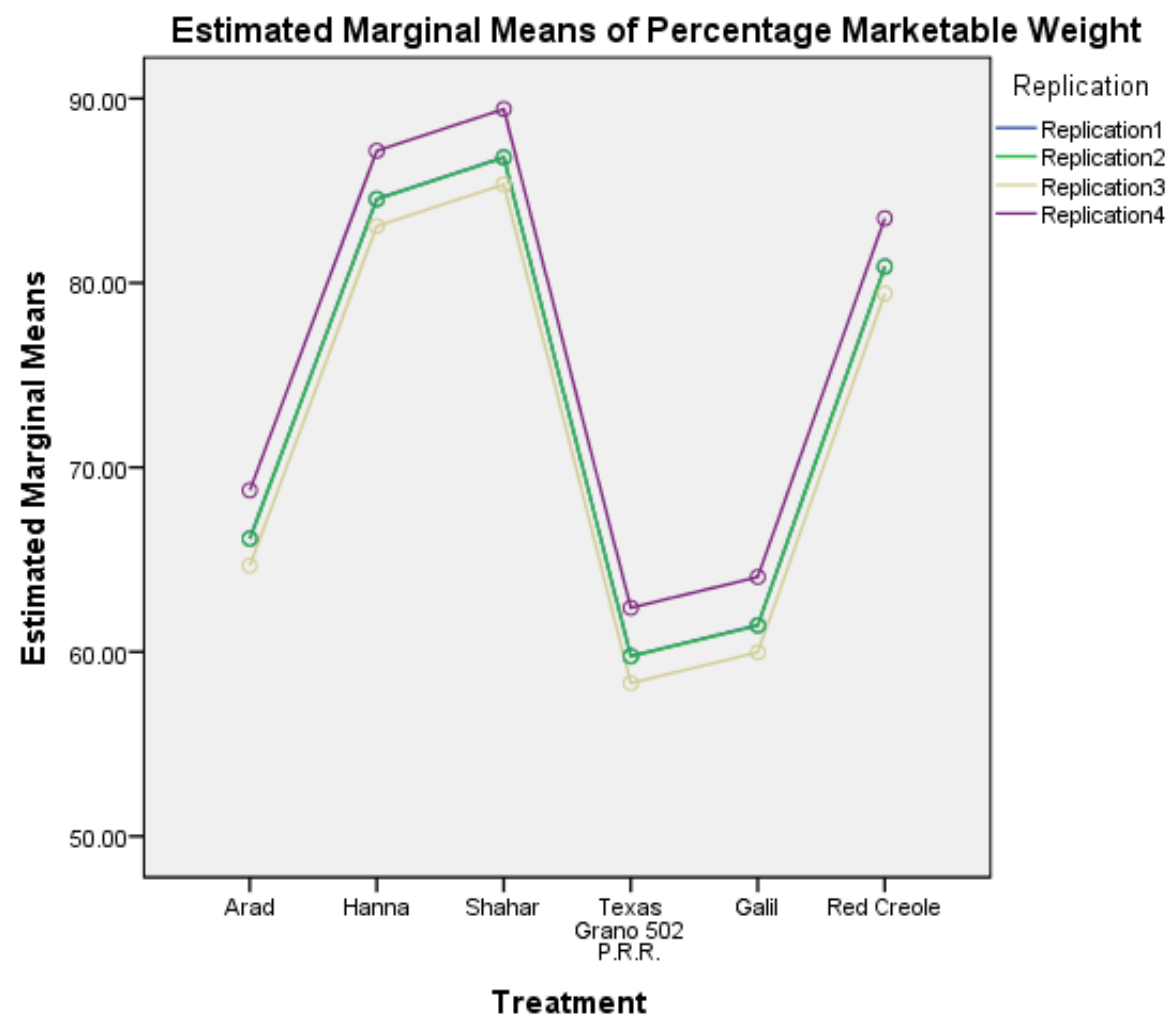

Figure 3. Estimated marginal means of percentage marketable onions of six varieties over the four replications

Texas Grano produced the highest total yield (54.70 t/ha) followed by Hanna which produced a total yield of 50.60 t/ha (Table 5). Therefore, Texas Grano emerges as the highest yielding onion variety followed by Hanna. Galil variety produced the lowest yield of $32.22 \mathrm{t} / \mathrm{ha}$. It indicated that Texas Grano is well adapted to the climatic and environmental conditions whereas the Galil did not. However, the highest marketable yield was produced by Hanna 43.01 t/ha where as Galil produced the lowest marketable yield (19.86 t/ha) (Table 5). The highest marketable yield produced by Hanna and the lowest by Galil was because of the fact that Hanna and Galil varities produced the highest and the lowest yield, respectively which was contributed by the unmarketable bulbs namely, small bulbs and bolters bulbs. Beside the fact that Shahar produced the highest marketable percentage yield (87.10\%), the marketable yield produced by Hanna (43.01t/ha) was still higher by 7.59 t/ha than the marketable yield produced by Shahar (35.42\%). In other words, it can be concluded that Hanna is the best variety which adapted well in the climatic conditions of Botswana and therefore, Hanna variety is the best onion variety to be grown as the farmers will be able to sell higher quantity of onions and obviously, obtain higher income. The Ministry of Agriculture can assist in importing seeds of Hanna and Shahar variety from South Africa to ensure the availability at a reasonable price. To boost and ensure the onion production in the country, these varieties can be distributed free of cost to the potentially viable onion growers through the existing Agro Service Centers across the country. Texas Grano variety has been a very common and popular onion variety among farmers only because of its easy availability and cheaper price of seeds. But Texas Grano variety yielded the lowest marketable percentage yield (60\%) contributed by high number of bolters and double onions. Therefore, the farmers should are not recommended for growing Texas Garno variety. Again, Texas Garano is a long term maturing varieties therefore; Texas Garano can be grown for harvesting onions as green as it produces good bulb and large size of leaves. Also, high number of bolters and double onion bulbs produced by Texas Grano is not a really a quality issue for consumers when green onion are used as green vegetables, not for storing for future use.

\subsection{Farmer's Perceptions on the Preference of Onion Varieties}

The ranking of onion varieties based on the perceptions of the farmers are presented in Table 6 which indicated that the farmers ranked variety Hanna followed by Shahar as the most preferred onion variety.

Table 6. Ranking of Onion Varieties Based on Farmers' Perceptions on Various Characters

\begin{tabular}{|c|c|c|c|c|c|c|c|}
\hline Variety & Yield & Color & Shape & Size & Availability of seeds & Total Points & Ranking \\
\hline Hanna & 2 & 2 & 1 & 1 & 3 & 9 & 1 \\
\hline Shahar & 3 & 1 & 2 & 4 & 4 & 14 & 2 \\
\hline Texas Grano 502 PRR & 1 & 6 & 4 & 6 & 1 & 18 & 4 \\
\hline Red Creole & 4 & 3 & 3 & 2 & 2 & 15 & 3 \\
\hline Arad & 5 & 5 & 4 & 2 & 5 & 21 & 5 \\
\hline Galil & 6 & 4 & 6 & 5 & 6 & 27 & 6 \\
\hline
\end{tabular}

Preference Scale $1-6$ (Highest preference $=1$ to Lowest preference $=6$ ) 
The farmers perceived and ranked onion variety Hanna number one as this variety produced good size bulbs of attractive shape and colour and better yield. Shahar was ranked number two among the six varieties. Galil was the lowest ranked $\left(6^{\text {th }}\right)$ because farmers did not appreciate its color, shape, size and low yield as well as difficult access to the seeds in the local market. However, based on the availability of seeds, Texas Grano was ranked number one. Texas Grano 502 PRR can be a better option for harvesting as green onions as it takes long to be matured and also very high percentage of unmarketable bulbs. Red Creole variety was placed at rank three as the reliable availability of seeds at cheaper price. Also, the farmers were attracted by Red Creole as this variety produced medium size bulbs of attractive color. Red Creole produce good yield and is late maturing and, therefore can be sold when there are no onions in the market which can attract good income. It is recommended that Red Creole together with Hanna and Shahar varieties of onions should be evaluated in different parts of Botswana and different planting dates should also be experimented. It was observed that the high cost of seeds and non availability of high yielding varieties such as Hanna and Shahar is a constraint in the adoption of onion varieties by farmers in Botswana which hinders the onion productivity in the country.

\section{Conclusion and Recommendations}

The results indicated that Hanna was the best onion variety as it produced the highest marketable yield of $43.01 \mathrm{t} / \mathrm{ha}$. However, Texas Grano produced the highest total yield of $54.07 \mathrm{t} / \mathrm{ha}$ t/ha but produced a very low marketable yield (32.22 t/ha) because of the lowest marketable percentage (60\%). Based on varietal characteristics of bulb shape, bulb size, good yield, easy availability of seeds and cheaper price of seeds in the local market, farmers also rated onion variety Hanna the best variety followed by Shahar. Beside the fact that the seeds of Texas Grano are cheaper and available in local market, it is recommended that farmers should not grow Texas Grano variety because of its low marketable yield due to the lowest marketable percentage. Observing the yield and farmer's perception, it can be concluded that Hanna is be the best onion variety followed by Shahar which can improve onion production in Botswana and therefore should be promoted for cultivation in Botswana. The Ministry of Agriculture along with the potential farmers across the country provides can effective platform for development and evaluation of onion new varieties. Planting dates can be a determining factor in productivity performance of the onion varieties and therefore; effects of different planting dates on yield of onion varieties especially, Hanna, Shahar and Red Creole should be considered for future research.

\section{Acknowledgement}

The author would like to acknowledge the support from the Department of Agricultural Research, Ministry of Agriculture, Republic of Botswana and the cooperative farmer for providing the opportunity to conduct this experiment during his tenure as an Agricultural Research Officer. The author is thankful to Dr. G.C.Wiles (Principal Agricultural Research Officer), Ms. Mercy Marope (Assistant Agricultural Research Officer) and Ms. Dijisiwa Kaisara (Technical Officer) for the great help in conducting the experiment.

\section{References}

[1] Ado, P.O. (2001). Onion cultivation. Onion Newsletter, 20: 30-34.

[2] Ahmad, S., Chohan, T.Z. and Saddozai, K.N... 2008. An investigation into cost and revenue of onion production in Azad Jammu Kashmir. Sarhad Journal of Agriculture, 24 (4): 737-743.

[3] Anon (1985). Annual Report for the division of Arable Crops Research 1983-84, Department of Agricultural Research, Department of Agricultural Research, Ministry of Agriculture, Government of Botswana, Gaborone, Botswana.

[4] Anon (1986). Annual Report for the division of Arable Crops Research 1984-85, Department of Agricultural Research, Department of Agricultural Research, Ministry of Agriculture, Government of Botswana, Gaborone, Botswana..

[5] Anon (1987). Annual Report for the division of Arable Crops Research 1985-86, Department of Agricultural Research, Department of Agricultural Research, Ministry of Agriculture, Government of Botswana, Gaborone, Botswana.

[6] Baliyan, S.P. (2006). On-farm vegetable variety trials report. Department of Agricultural Research, Ministry of Agriculture, Government of Botswana, Gaborone, Botswana.

[7] Baliyan, S.P. and Kghati, D.L. (2009). Production and marketing problems in small scale horticultural farming in Botswana. Proceeding of the XVI International Symposium on Horticultural Economics and Management. Acta Hort. (ISHS) 831: 31-40.

[8] Best, K. (2000). Red Onion Cultivars Trial. Horticultural Nova Scotia, Kentville Agricultural Centre, Nova Scotia, Canada. pp. 10-13.

[9] Brewster, J.L. (2008). Onions and other Vegetable Alliums. (2nd ed.), CAB International, North America.

[10] Department of Agricultural Research. (2006). Manual for vegetable production in Botswana. Ministry of Agriculture, Government of Botswana, Gaborone, Botswana.

[11] F.A.O. (2012). Production Year Book: Food and Agriculture Organisation, Rome, Italy.

[12] Greenbaum, T.L. (1993). The Handbook of Focus Group Research. New York: Lexington Books.

[13] Hayslip, N.C., Gull, D.D., Guzman, V.L., Shumaker, J.R. and Sonoda, R.M. (1987). Bulb onion production in Florida. FL Coop. Ext. Svc. Bull. 238 p.

[14] Jilani, M.S. and Ghafoor, A. (2003). Screening of Local Onion Varieties for Bulb Formation. International Journal of Agriculture and Biology, 5 (2), 129-133.

[15] Ijoyah, M.O., Rakotomavo, H. and Naiken, M.V. (2008).Yield Performance of Four Onion (Allium Cepa L.) Varieties Compared With The Local Variety Under Open Field Conditions at Anse Boileau, Seychelles. Journal of Science and Technology, 28(3), 28-33.

[16] Kimani, P.M., Kariuki, J.W., Peters, R. and Rabinowitch, H.D. (1993). Influence of the Environment on the Performance of Some Onion Cultivars in Kenya. African Crop Science journal, 1(1), 1523.

[17] Krueger, R.A. (1988). Focus Groups: A Practical Guide for Applied Research. Newbury Park, CA: Sage. 179p.

[18] Mettananda, K.A. and Fordham, R. (2001). The Effects of Plant Size and Leaf Number on the Bulbing of Tropical Short-day Onion Cultivars (Allium cepa L.) Under Controlled Environments. Journal of Horticultural Science, 14(5), 22-31.

[19] Shah, S.T., Sajid, M., Alam, R., Rab, A., Mateen, I. J., Ali, A. and Wahid, F. (2012). Comparative study of onion cultivars at Mardan, Khyber Pakhtunkhwa - Pakistan. Sarhad Journal of Agriculture, 28(3), 399-402.

[20] Smith, C. (2003). Genetic Analysis of Quercetin in Onion (Allium cepa L.) 'Laddy Raider'. The Texas Journal of Agriculture and Natural Resource, 16, 24-28.

[21] Steel, R.G.D. and Torrie, J.H. (1980). Principles and Procedures of Statistics. A biometrical approach. 2nd edition. McGraw-Hill, New York, USA, pp. 20-90. 
[22] Wiles, G.C. (2006). On-station vegetable variety trials report. Department of Agricultural Research, Ministry of Agriculture,

\section{Government of Botswana, Gaborone, Botswana.}

\section{Appendix 1}

Pictures of dry bulbs of the six varieties of onions
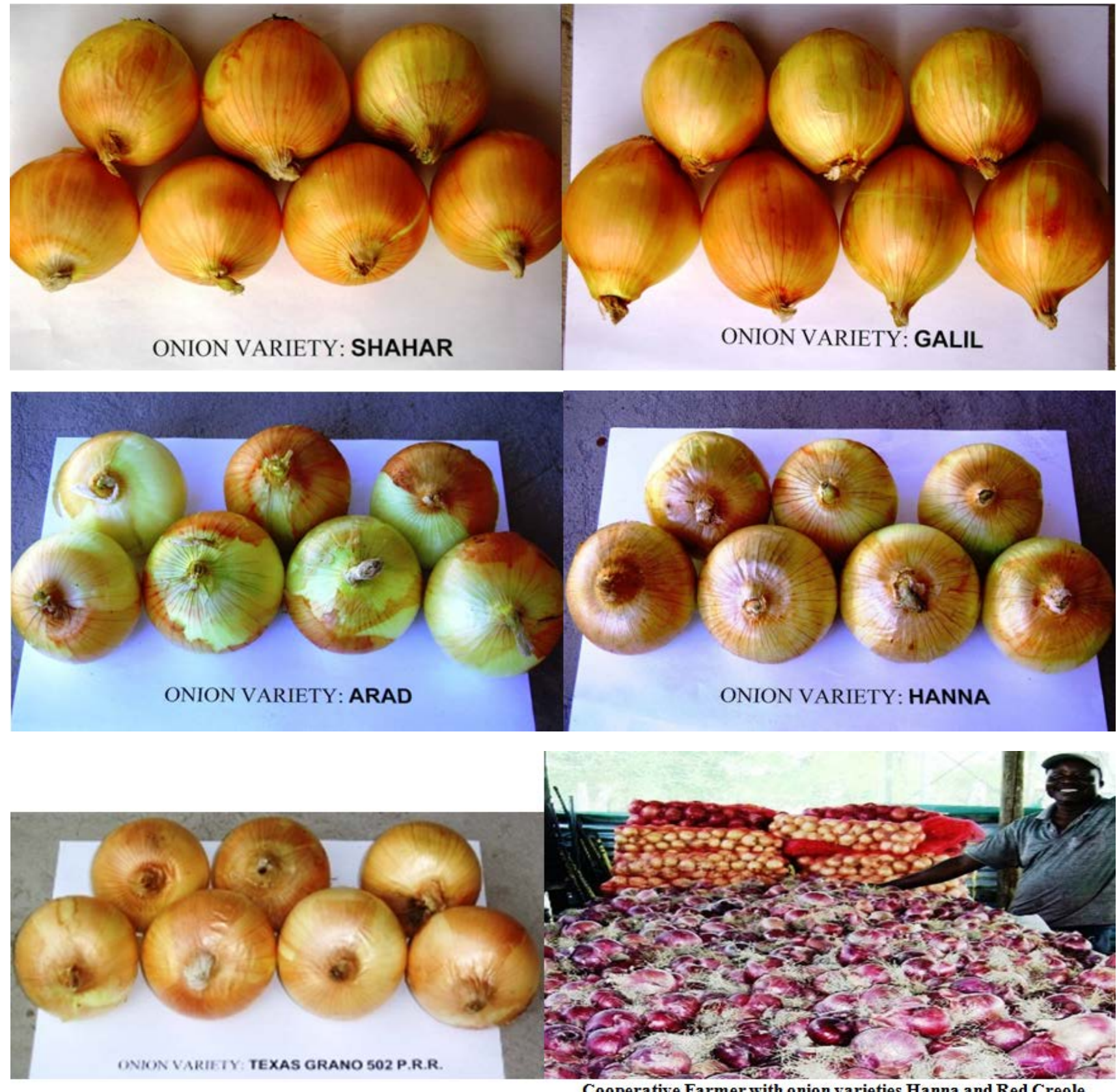

Coopera tive Farmer with onion varieties Hanna and Red Creole 